FACTUM: Jurnal Sejarah dan Pendidikan Sejarah, 9 (1). 2020. 85-94

\title{
UPAYA MENINGKATKAN KETERAMPILAN KOMUNIKASI SISWA DALAM PEMBELAJARAN SEJARAH MELALUI STRATEGI GIVING QUESTION GETTING ANSWER
}

\author{
Oleh: \\ Ulfi Indriyani ${ }^{1}$
}

Naskah diterima : 28 Januari 2020, Naskah direvisi : 28 Februari 2020, Naskah disetujui : 20 Maret 2020

To cite this article: Indriyani, U., Supriatna, N., Kuarniawti, Y. (2020). Upaya meningkatkan keterampilan komunikasi siswa dalam pembelajaran sejarah melalui strategi giving question getting answer. FACTUM: Jurnal Pendidik dan Peneliti Sejarah, 9 (1). 2020. 85-94, DOI: https://doi.org/10.17509/factum.v9i1.23071

\begin{abstract}
This research aimed to improve students communication skill in learning history by implementing Giving Question Getting Answer Strategy. Based on pre-research observations showed the lack of communication skill of students in learning history. The problem emerged because, in the learning process, communication conducted in one direction. Therefore, researchers conducted the Classroom Action Research method with Kemmis-Taggart design which includes four activities to be carried out in each cycle, namely plan, act, observe, and reflect. Data collecting technique that used in this research were observation, field notes, interviews and documentation studies. The indicators consisted of asking questions, presenting information, draw a conclusion, presentation clarity, mastery of subject matter, interaction in the group and giving feedback, which was developed into three sub-indicators. All of those aspects have experienced a good increase in each cycle. The average percentage of overall indicator score in Cycle I was 47,2\%, then it increased in Cycle II to 68,3\%, in Cycle III it increased again to 82\%, add in Cycle IV it reached 92,8\%. Thus, it can be concluded that students communication skill in learning history can be improved after the implementation of Giving Question Getting Answer strategy in fourcycle.
\end{abstract}

Keywords: Communication skill, learning history, giving question getting answer

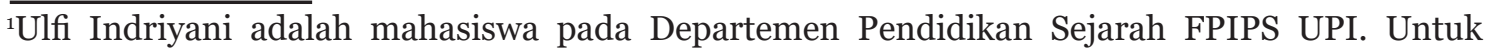
kepentingan akademik penulis dapat dihubungi melalui alamat email : indriyaniulfi@gmail.com. 


\section{PENDAHULUAN}

Pembelajaran merupakan usaha pendidik untuk mewujudkan terjadinya proses pemerolehan pengetahuan, penguasaan kemahiran, pembentukan sikap, dan kepercayaan pada peserta didik (Hanafy, 2004, hlm. 74). Oleh karena itu melalui proses pembelajaran siswa diharapkan mengalami peningkatan dalam berbagai aspek seperti pengetahuan, sikap dan keterampilan, sebagaimana salah satu tujuan dari proses pembelajaran itu sendiri yakni meningkatkan keterampilan siswa.

Salah satu aspek penting yang harus dimiliki oleh siswa dalam proses pembelajaran adalah keterampilan komunikasi. Menurut Rogers dan Kincaid (dalam Cangara, 1998, hlm. 19) komunikasi merupakan proses dimana dua orang atau lebih membentuk atau melakukan pertukaran informasi dengan satu sama lainnya, dimana selanjutnya akan timbul saling pengertian yang mendalam. Jadi dapat dikatakan bahwa komunikasi adalah proses penyampaian dan pertukaran ide, gagasan, informasi dan perasaan oleh lebih dari satu individu serta proses timbulnya makna pada ide atau gagasan yang disampaikan dimana akan timbul pengertian yang mendalam sehingga akan memunculkan hubungan timbal balik (feedback) untuk merumuskan informasi dan saling mempengaruhinya sehingga terbentuk argumen dan sikap.

Sylvia Moss dan Stewart L. Tubss (dalam Mulyana, 2005, hlm. 69) mengungkapkan bahwa komunikasi bisa dikatakan efektif ketika seseorang berhasil menyampaikan maksudnya atau ketika rangsangan yang dimaksudkan dan disampaikan oleh pengirim saling berhubungan dengan rangsangan yang ditangkap dan dimengerti oleh penerima. Dalam kaitannya dengan proses pembelajaran sejarah, apabila pesan yang hendak disampaikan dalam hal ini materi ajar bisa diterima dan dimengerti serta memunculkan feedback yang baik dari guru kepada siswa, barulah komunikasi dapat disebut efektif. Komunikasi yang efektif akan memberikan dampak yang besar pada keberhasilan pencapaian tujuan dalam proses pembelajaran.

Dengan demikian keterampilan komunikasi dapat membantu siswa dalam proses pembelajaran untuk mencapai tujuan pembelajaran secara efektif. Siswa menjadi lebih mudah untuk mengkomunikasikan berbagai hal baik secara lisan maupun tulisan terkait materi pembelajaran dengan adanya keterampilan komunikasi. Maka akan berpengaruh terhadap peningkatan pemahaman siswa pada materi yang dipelajari di sekolah, termasuk dalam pembelajaran sejarah.

Proses kegiatan belajar mengajar sejarah lebih menekankan pada aktivitas siswa agar pembelajaran menjadi lebih bermakna, salah satu unsur dari aktivitas belajar siswa disini adalah terjadinya komunikasi yang efektif. Akan tetapi dari hasil observasi selama pra penelitian yang peneliti lakukan pada siswa kelas XI MIPA 2 SMA Negeri 15 Bandung ditemukan beberapa permasalahan yang mengarah pada rendahnya keterampilan komunikasi siswa dalam pembelajaran sejarah. Terlihat dalam kegiatan apersepsi guru melakukan tanyajawab mengenai materi pembelajaran pada pertemuan sebelumnya, tidak ada siswa yang menjawab dengan alasan mereka tidak mengingat materi tersebut, ketika guru mengatakan bahwa yang menjawab akan dicatat namanya dan diberi nilai serta memperbolehkan untuk 
membuka LKS barulah ada satu dua siswa yang menjawab itupun hanya sebatas membacakan kembali apa yang tercantum di dalam LKS. Kemudian, ketika guru memberikan kesempatan kepada siswa untuk bertanya atau berpendapat setelah guru menyampaikan materi pembelajaran, tidak ada satu pun siswa yang mengajukan pertanyaan maupun mengemukakan pendapatnya.

Pada pertemuan berikutnya guru menggunakan metode diskusi dengan membagi siswa ke dalam kelompokkelompok kecil kemudian setiap kelompok bergiliran mempresentasikan tugasnya. Pada proses presentasi ini siswa hanya membacakan isi laporan diskusi mereka, isi laporan tersebut pun sama persis dengan yang tercantum dalam buku teks, tidak dijelaskan dengan kata-kata sendiri. Memasuki sesi tanya jawab, tidak ada anggota kelompok lain yang mengajukan pertanyaan, guru harus menunjuk terlebih dahulu barulah ada siswa yang mengajukan pertanyaan dan pertanyaan yang diajukan pun masih sebatas pengetahuan dasar seperti apa, siapa, dimana dan kapan.

Salah satu upaya yang dapat dilakukan untuk meningkatkan keterampilan berkomunikasi siswa dalam pembelajaran sejarah adalah dengan menerapkan strategi pembelajaran Giving Question Getting Answer karena strategi ini merupakan hasil modifikasi metode ceramah dengan metode tanya jawab yang dikolaborasikan dengan menggunakan kartu atau potongan-potongan kertas sebagai media pembelajarannya, yang dikembangkan dengan tujuan melatih siswa agar mempunyai keterampilan dan kemampuan bertanya jawab (Silbermen, 2009, hlm. 244). Penerapan strategi Giving Questions Getting Answer pada pembelajaran sejarah akan melatih siswa dalam bertanya dan mengolah pertanyaan serta membuat siswa dapat berpartisipasi secara aktif sehingga akan menumbuhkan keterampilan komunikasi siswa dalam pembelajaran sejarah.

Oleh sebab itu, peneliti mengambil pokok permasalahan "Bagaimana upaya untuk meningkatkan keterampilan komunikasi siswa dalam pembelajaran sejarah melalui strategi Giving Question Getting Answer". Penelitian ini bertujuan untuk meningkatkan keterampilan komunikasi siswa dalam pembelajaran sejarah.

\section{METODE PENELITIAN}

Dalam suatu penelitian penggunaan metode penelitian adalah hal yang sangat penting. Metode penelitian yang digunakan dalam penelitian ini adalah Penelitian Tindakan Kelas (Classroom Action Research). Penelitian Tindakan Kelas menurut Kemmis (dalam Wiriaatmadja, 2012, hlm. 12) adalah sebuah bentuk inkuiri refleksi yang dilakukan secara kemitraan mengenai situasi sosial tertentu (termasuk pendidikan) untuk meningkatkan rasional dan keadilan dari kegiatan praktek sosial dan pendidikan, pemahaman mengenai praktek pendidikan dan situasi yang mendukung terlaksananya praktek pendidikan ini. Sedangkan menurut Arikunto (2009) Penelitian Tindakan Kelas merupakan suatu pencermatan terhadap kegiatan belajar berupa sebuah tindakan yang sengaja dimunculkan dan terjadi dalam kelas secara bersamaan dengan arahan dari guru yang dilakukan oleh siswa. Secara sederhana Penelitian Tindakan Kelas adalah bagaimana guru dapat mengorganisasikan kondisi pembelajaran siswa guna mencoba 
perbaikan pembelajaran dan melihat pengaruh dari upaya tersebut.

Oleh karena itu, metode penelitian tindakan kelas tepat digunakan karena penelitian ini bukan untuk membuktikan suatu teori tertentu, melainkan untuk menemukan dan mengaplikasikan cara yang tepat dalam mengatasi suatu permasalahan yang terjadi dalam proses pembelajaran di kelas.

Sedangkan desain Penelitian Tindakan Kelas model spiral yang dikembangkan oleh Kemmis dan Mc. Taggart. Penelitian Tindakan Kelas model Kemmis dan Mc Taggart terdiri dari acting (tindakan) dengan kegiatan observing (pengamatan) dijadikan sebagai satu kesatuan, sehingga dalam pelaksanaan siklusnya lebih mudah dan mengefektifkan waktu. Desain Penelitian Tindakan Kelas Model Kemmis dan Mc Taggart ini sendiri terdiri dari empat tahapan dalam setiap siklusnya yaitu kegiatan Perencanaan (Plan), Tindakan (Act), Pengamatan (Observe), dan Refleksi (Reflect).

Penelitian ini dilakukan di SMA Negeri 15 Bandung yang berlokasi di Jalan Sarimanis I No.1, Sarijadi, Kecamatan Sukajadi, Kota Bandung, Jawa Barat 40151. Dengan subjek penelitian siswa kelas XI MIPA 2 SMA Negeri 15 Bandung yang terdiri atas 33 orang siswa. Pemilihan kelas tersebut tidak terlepas dari hasil observasi pra penelitian yang menunjukkan rendahnya keterampilan komunikasi siswa dalam proses pembelajaran sejarah.

Adapun instrumen penelitian yang digunakan dalam penelitian ini adalah lembar pedoman observasi, lembar catatan lapangan, lembar pedoman wawancara dan dokumentasi. Teknik pengumpulan data yang dilakukan oleh peneliti adalah dengan observasi, catatan lapangan, wawancara dan studi dokumentasi. Kemudian hasil penelitian ini diolah dan divalidasi dengan triangulasi, member check dan expert opinion.

\section{HASIL PENELITIAN DAN PEMBAHASAN}

Berdasarkan hasil observasi pra penelitian yang telah dilakukan, peneliti mengidentifikasi permasalahan yang ditemukan di kelas dan melakukan perencanaan penerapan strategi Giving Question Getting Answer untuk meningkatkan keterampilan komunikasi siswa dalam pembelajaran sejarah di kelas XI MIPA 2. Adapun perencanaan yang dilakukan oleh peneliti diantaranya mempersiapkan perangkat pembelajaran yang akan digunakan seperti RPP, materi ajar, media pembelajaran berupa power point serta amplop-amplop berisi kartu pertanyaan dan pernyataan siswa, juga instrumen penelitian yang terdiri dari lembar catatan lapangan untuk mencatat segala perilaku siswa dan guru selama tindakan berlangsung, lembar observasi keterampilan komunikasi siswa dan lembar observasi penerapan strategi pembelajaran Giving Question Getting Answer beserta rubrik penilaiannya untuk memudahkan observer menentukan skor ketika mengamati siswa.

Sebelum melakukan kegiatan inti pembelajaran, pada kegiatan pendahuluan guru terlebih dahulu mengkondisikan siswa kemudian memeriksa kehadiran mereka, setelah itu guru melakukan apersepsi mengenai materi pembelajaran sebelumnya, baru setelah itu menyampaikan tema materi pembelajaran hari ini beserta tujuan pembelajarannya. 
Pada kegiatan pemberian pengantar materi, guru mengulas sedikit mengenai materi yang akan dibahas oleh siswa. Setelah itu guru membagikan dua buah amplop berisi kartu untuk menuliskan pertanyaan untuk diajukan dan topik yang dapat mereka jelaskan kepada masingmasing siswa. Memasuki kegiatan dalam kelompok, pertama siswa berdiskusi untuk menyeleksi pertanyaan yang akan diajukan dan topik yang akan dijelaskan. Setelah itu, siswa yang topiknya terpilih untuk dijelaskan di depan kelas atau yang selanjutnya disebut komunikator kelompok terlebih dahulu menjelaskan topik tersebut kepada anggota kelompoknya. Kemudian pembelajaran dilanjutkan dengan kegiatan tanya jawab. Pertanyaan yang telah dipilih oleh masing-masing kelompok secara bergantian disampaikan di depan kelas, kemudian kelompok lain yang bisa menjawabnya dipersilakan untuk menjawab sementara anggota kelompok lain yang belum memiliki kesempatan untuk menjawab diberi kesempatan untuk menanggapi atau menambahkan jawaban yang diberikan kelompok lain.

Setelah semua pertanyaan dari setiap kelompok terjawab, kegiatan pembelajaran dilanjutkan dengan mempresentasikan topik yang dipilih masing-masing kelompok oleh seorang komunikator kelas yang dipilih secara acak oleh guru dari setiap kelompoknya. Terakhir sebelum menutup kegiatan pembelajaran guru memberikan kesempatan kepada salah satu siswa yang mau menyampaikan kesimpulan kegiatan pembelajaran hari ini di depan kelas.

Penelitian ini berfokus pada peningkatan keterampilan komunikasi siswa dalam pembelajaran sejarah dengan berpedoman pada beberapa indikator yang dijadikan patokan dalam penilaian. Hal ini dilakukan untuk melihat peningkatan yang terjadi selama dilakukan penelitian. Indikator-indikator keterampilan komunikasi yang digunakan dalam penelitian ini adalah, pertama pejelasan penyampaian, kedua penguasaan materi, ketiga interaksi dalam kelompok, dan keempat pemberian respon. Sedangkan indikator yang dijadikan patokan untuk menilai penerapan strategi pembelajaran Giving Question Getting Answer dalam penelitian ini adalah, pertama mengajukan pertanyaan, kedua menyampaikan informasi, dan ketiga menarik kesimpulan. Masing-masing indikator tersebut kemudian dikembangkan menjadi tiga sub indikator. Hasil skor yang diperoleh dari setiap indikator tersebut kemudian diolah dalam bentuk presentase untuk memudahkan peneliti menganalisis peningkatan yang terjadi pada setiap siklusnya.

Berdasarkan hasil temuan di kelas penelitian yang diberikan tindakan untuk meningkatkan keterampilan komunikasi siswa dalam pembelajaran sejarah dengan menerapkan strategi pembelajaran Giving Question Getting Answer yang diperoleh melalui hasil observasi keterampilan komunikasi, penerapan strategi pembelajaran Giving Question Getting Answer, catatan lapangan, serta hasil wawancara dengan siswa dan guru mitra, diketahui bahwa keterampilan komunikasi siswa kelas XI MIPA 2 SMA Negeri 15 Bandung mengalami peningkatan dari Siklus I sampai dengan Siklus IV.

Perolehan rata-rata presentase siswa dalam aspek keterampilan komunikasi dalam pembelajaran sejarah yang 
dievaluasi melalui kegiatan dalam kelompok menunjukkan presentase sebesar 52,7\% pada Siklus I, 88,8\% pada Siklus II, 94,4\% pada Siklus III, dan 97,2\% pada Siklus IV. Penilaian tersebut dilihat dari kemampuan siswa dalam berbicara dengan volume suara yang terdengar jelas baik ketika mengajukan pertanyaan maupun ketika menyampaikan pendapat, mampu berbicara dengan lancar tanpa terbata-bata, mampu menyampaikan pendapat dengan katakatanya sendiri, menjawab pertanyaan yang disampaikan oleh kelompok lain dengan benar, menjelaskan keterkaitan antar konsep dalam materi yang sedang dibahas, mengungkapkan argumen yang relevan dengan materi yang dibahas pada saat proses tanya jawab, menjelaskan informasi yang dimiliki kepada anggota kelompoknya, berperan aktif dalam bertukar pendapat dengan anggota kelompoknya, ikut berdiskusi dalam kelompok, menghargai temannya dengan memperhatikan dan tidak ikut berbicara ketika temannya sedang menyampaikan pendapatnya, bersikap responsif dengan menanggapi jawaban yang diberikan oleh kelompok lain, serta mencatat hal-hal yang dianggap penting ketika kegiatan pembelajaran berlangsung.

Hal-hal tersebut sesuai dengan nilainilai yang terkandung di dalam lima hukum komunikasi efektif yang dikeluarkan oleh Supeno (dalam Naim, 2011, hlm. 4749), yang secara garis besar menyatakan bahwa, setiap individu yang terlibat dalam proses komunikasi sebaiknya mampu bersikap saling menghargai satu sama lain serta mampu menempatkan diri secara tepat dan bersikap rendah hati, konten materi disampaikan secara lugas, menarik, dan jelas maksudnya sehingga dapat diterima dengan baik sehingga tidak akan menimbulkan multitafsir.

Sementara dilihat dari hasil observasi penerapan strategi pembelajaran Giving Question Getting Answer yang dievaluasi secara individual, siswa memperoleh presentase rata-rata peningkatan indikator secara keseluruhan sebesar 41,7\% pada Siklus I, 47,8\% pada Siklus II, $69,6 \%$ pada Siklus III, dan $88,5 \%$ pada Siklus IV. Siswa telah mampu membuat sebuah pertanyaan yang tidak hanya bersifat faktual, pertanyaan yang dibuat juga relevan dengan materi yang sedang dibahas, kemudian siswa dapat menuliskan pertanyaan tersebut dengan bahasa Indonesia yang baik dan benar. Siswa mampu menyampaikan informasi dengan menjelaskan salah satu topik dalam materi yang sedang dibahas berdasarkan sumber-sumber yang relevan baik secara lisan maupun dalam bentuk essay, serta mampu membuat kesimpulan berdasarkan hasil pengamatannya selama kegiatan pembelajaran berlangsung yang menjawab permasalahan secara singkat dan menggunakan bahasanya sendiri.

Hal-hal tersebut di atas sejalan dengan pendapat Said (2016, hlm. 78) dimana strategi pembelajaran Giving Question Getting Answer yang merupakan strategi memberi dan menerima adalah penguasaan materi pembelajaran melalui kartu, berpasangan dengan saling bertukar informasi, dan pengevaluasian yang bertujuan mengetahui pengetahuan dan penguasaan siswa terhadap materi yang diberikan dalam kartu dan kartu pasangannya. Strategi memberi dan menerima merupakan pembelajaran yang menuntut siswa memahami materi pelajaran yang diberikan guru dan melalui 
teman lain. Dengan demikian dalam proses pembelajaran juga akan terjalin komunikasi baik di antara guru dengan siswa maupun di antara sesama siswa.

Berdasarkan pemaparan di atas, untuk membuktikan bahwa penerapan strategi pembelajaran Giving Question Getting Answer dapat meningkatkan keterampilan komunikasi siswa, berikut ini akan disajikan gambaran ketercapaian peningkatan keterampilan komunikasi siswa dalam pembelajaran sejarah dengan menerapkan strategi pembelajaran Giving Question Getting Answer dari Siklus I sampai dengan Siklus IV. menjadi 82\%. Dan pada Siklus IV kembali meningkat menjadi 92,8\%. Peningkatan jumlah rata-rata presentase dalam aspek keterampilan komunikasi siswa dalam pembelajaran sejarah dengan menerapkan strategi pembelajaran Giving Question Getting Answer ini memperlihatkan perubahan ke arah yang positif.

Berdasarkan grafik yang akan disajikan berikut ini dapat dilihat bahwa keterampilan komunikasi siswa mengalami peningkatan setelah diberikan tindakan dengan menerapkan strategi pembelajaran Giving Question Getting Answer. Hasil penelitian ini menunjukkan

Tabel 10.1

Perkembangan Ketercapaian Keterampilan Komunikasi Siswa Melalui Penerapan Strategi Pembelajaran Giving Question Getting Answer

\begin{tabular}{|l|l|l|l|}
\hline \multirow{2}{*}{ Siklus } & \multicolumn{2}{|c|}{ Ketercapaian Indikator } & $\begin{array}{l}\text { Akumulasi Rata- } \\
\text { Rata Presentase }\end{array}$ \\
\cline { 2 - 4 } & $\begin{array}{l}\text { Keterampila n } \\
\text { Komunikasi }\end{array}$ & $\begin{array}{l}\text { Penerapan Strategi } \\
\text { Giving Question } \\
\text { Getting Answer }\end{array}$ & \\
\hline Siklus I & $52,7 \%$ & $41,7 \%$ & $47,2 \%$ \\
\hline Siklus II & $88,8 \%$ & $47,8 \%$ & $68,3 \%$ \\
\hline Siklus III & $94,4 \%$ & $69,6 \%$ & $82 \%$ \\
\hline Siklus IV & $97,2 \%$ & $88,5 \%$ & $92,8 \%$ \\
\hline
\end{tabular}

Jika diakumulasikan, pencapaian keterampilan komunikasi siswa dan penerapan strategi pembelajaran Giving Question Getting Answer pada Siklus I mendapat rata-rata presentase $47,2 \%$. Kemudian setelah diberikan tindakan pada Siklus II mengalami peningkatan rata-rata presentase menjadi 68,3\%. Pada Siklus III jumlah rata-rata presentase pencapaian siswa dalam hal keterampilan komunikasi dengan penerapan strategi pembelajaran Giving Question Getting Answer dalam pembelajaran sejarah meningkat lagi bahwa penerapan strategi pembelajaran Giving Question Getting Answer efektif untuk meningkatkan keterampilan komunikasi siswa di kelas XI MIPA 2 SMA Negeri 15 Bandung. Hal ini sesuai dengan salah satu tujuan pembelajaran sejarah yakni dapat mengembangkan keterampilan yang dimiliki oleh siswa, salah satunya keterampilan komunikasi. Dengan keterampilan komunikasi yang baik nantinya dapat membantu siswa untuk beradaptasi dengan kehidupan masyarakat. 
Gambar 10.1

Hasil Observasi Peningkatan Keterampilan Komunikasi Siswa dalam Pembelajaran Sejarah dengan Menerapkan Strategi Pembelajaran Giving Question Getting Answer

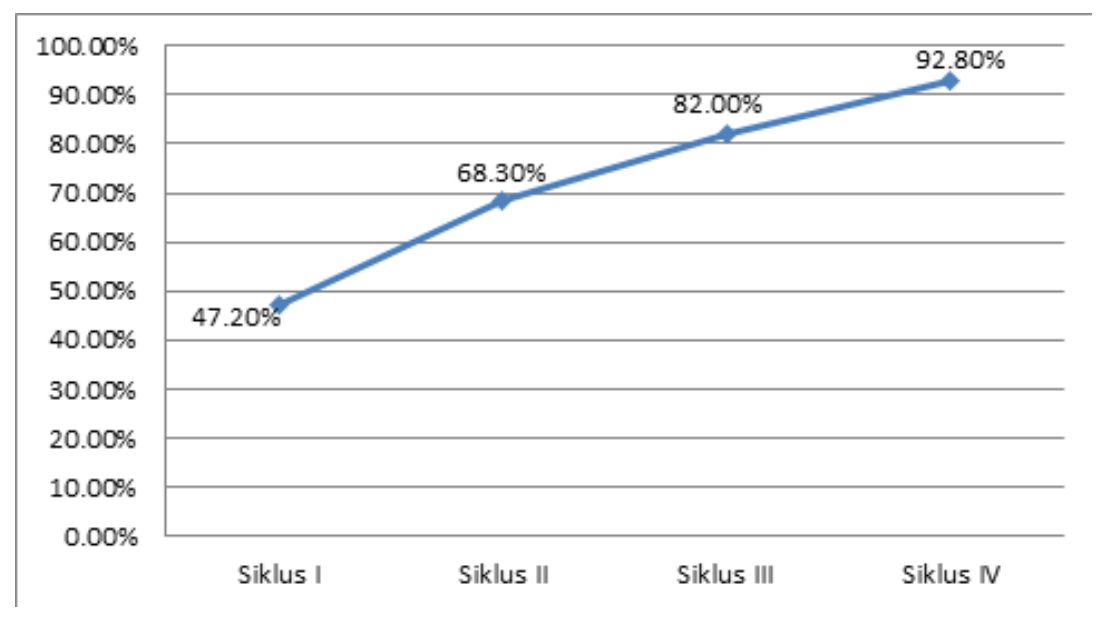

Selain dari hasil observasi yang telah dilakukan bersamaan dengan dilaksanakannya tindakan. Terdapat peningkatan keterampilan komunikasi siswa setelah diterapkannya strategi pembelajaran Giving Question Getting Answer juga didukung oleh hasil wawancara yang dilakukan dengan guru dan beberapa perwakilan siswa sebelum dan setelah dilaksanakannya tindakan. Menurut pendapat guru sejarah yang menjadi mitra peneliti penerapan strategi pembelajaran tersebut cukup bagus karena siswa menjadi lebih antusias selama proses pembelajaran sejarah. Sudah terjadi perubahan dalam hal keterampilan komunikasi siswa dengan peningkatan yang cukup signifikan, karena siswa lebih berperan aktif dalam proses kegiatan pembelajaran, mereka menjadi lebih berani untuk berbicara di kelas dengan bertanya maupun menyampaikan pendapat dan cukup menguasai materi yang disampaikan, sehingga dalam proses pembelajaran terjalin komunikasi secara dua arah tidak hanya guru dengan siswa tetapi juga di antara sesama siswa.

Sementara siswa yang peneliti wawancara berpendapat belajar sejarah menggunakan strategi pembelajaran Giving Question Getting Answer membuat mereka lebih mudah memahami materi yang disampaikan, kegiatan diskusi kelompok membuat mereka bisa mengerti materi dengan kalimat yang disusun dengan bahasa sendiri. Secara keseluruhan menurut mereka belajar sejarah dengan menggunakan strategi pembelajaran Giving Question Getting Answer lebih baik dibandingkan dengan metode ceramah biasa karena mereka menjadi lebih aktif. Setelah diterapkannya strategi pembelajaran Giving Question Getting Answer, mereka merasa lebih terlatih untuk mengajukan pertanyaan dan semakin percaya diri untuk berbicara di depan kelas. Dengan demikian dapat disimpulkan bahwa implementasi strategi pembelajaran ini terbukti efektif 
meningkatkan keterampilan komunikasi siswa dalam pembelajaran sejarah di kelas XI MIPA 2 SMA Negeri 15 Bandung.

\section{SIMPULAN}

Berdasarkan hasil penelitian tindakan kelas yang telah dilakukan di kelas XI MIPA 2 SMA Negeri 15 Bandung, maka dapat ditarik kesimpulan bahwa terjadi peningkatan dalam keterampilan komunikasi siswa dalam pembelajaran sejarah. Hal ini dapat dilihat dari beberapa perubahan yang terjadi pada siswa, yakni 1) Siswa sudah memiliki kemampuan menyampaikan dengan jelas baik ketika mengajukan pertanyaan maupun ketika mengemukakan pendapat; 2) Siswa mampu menguasai materi yang disampaikan komunikator kepada komunikan; 3) Siswa berinteraksi dengan anggota kelompok selama proses kegiatan diskusi berlangsung dan 4) Siswa mampu memberikan respon dalam proses kegiatan tanya jawab

\section{DAFTAR PUSTAKA}

Arikunto, S. (2009). Prosedur penelitian suatu pendekatan praktik. Yogyakarta: Rineka Cipta.

Cangara, Hafied. (2004). Pengantar ilmu komunikasi. Jakarta: PT Raja Grafindo Persada.

Hanafy, M. S. (2014). Konsep Belajar dan Pembelajaran. Jurnal Lentera Pendidikan, 17 (1), hlm. 66-79.

Mulyana, Deddy. (2005). Ilmu komunikasi suatu pengantar. Bandung: PT Remaja Rosdakarya.

Naim, N. (2012). Dasar-dasar komunikasi pendidikan. Jogjakarta: Ar-Ruzz Media.

Said, Alamsyah. Dkk. (2016). Strategi mengajar multiple intelligences. Jakarta: Prendamedia Group.

Silbermen, Melvin L. (2009). Active learning: 101 strategi pembelajaran aktif. Yogyakarta: Pustaka Insan Madani.

Wiriaatmadja, R. (2012).Metode penelitian tindakan kelas untuk meningkatkan kinerja guru dan dosen. Bandung: Remaja Rosdakarya. 
FACTUM

Volume 9 No.1, April 2020 